\title{
SECURITY POLICY OF THE BALTIC STATES AND ITS DETERMINING FACTORS
}

\author{
Lt. Col. Sławomir PIOTROWSKI, PhD \\ War Studies University, Warsaw, Poland \\ s.piotrowski@akademia.mil.pl
}

\begin{abstract}
The history of the nations living in today's Baltic States is marked by fighting against stronger neighbours: Russia, Poland, Sweden, Denmark and the German settlers in their territories. Unlike Lithuanians, Estonians and Latvians failed to create their own statehood before the $20^{\text {th }}$ century. The Lithuanians created their own state, a powerful one, which then became a part of an even wider state organism - the Polish-Lithuanian Commonwealth. As a result, the security policy of Lithuania was identical to that of the First Republic of Poland. Although there were tribes living within the area of current Estonia and Latvia for many centuries up to the outbreak of World War I, the lands of Latvia and Estonia had been changing owners and had been under the rule of almost all neighbouring countries. As a result of the positive outcome of the First World War, but also thanks to their efforts, the Baltic States regained independence in order to lose it after only 20 years, as a consequence of another war. After restoring independence with the collapse of the Soviet Union, the Baltic States realised that even acting together they were unable to defend themselves against a potential aggressor. As a result, they decided to follow in the footsteps of other countries of the former Eastern Bloc (e.g. Poland and Slovakia) and to integrate with Western European structures such as NATO and the EU. Following NATO inclusion, the security strategies of the Baltic States have been revised in line with the changes in their surrounding geopolitical environment.
\end{abstract}

Keywords: security policy, European security, Baltic States. 


\section{Introduction}

The processes which occur in the security environment fall in the area of security sciences and international relations sciences. In international relations sciences, the research is focused mainly on the level of the international systems and the main entities (states and organisations) which function in this system. The security policy of a state is influenced by the historical experience of a given state. However, it is determined above all by the changes which take place in the security environment which surrounds the policy. The increasingly aggressive Kremlin policy towards its neighbouring countries, which is a derivative of the more and more visible aspirations of the Russian Federation to regaining the international position it lost at the beginning of the 1990s, causes concern in many countries. Due to the fact that the actions taken by some states in this matter and the official stances presented are almost homogeneous, it is worth grouping a few such states in order to obtain a wider perspective on a given region. The above observation is reflected in the topic the author has chosen for this work. The purpose of the research is to identify the determinants which condition the development directions and the actions taken by the Baltic States to carry out an effective security policy. The research problem which arises from the adopted purpose of the research is an attempt to answer the following question: How has the security policy of the Baltic states evolved since the moment they gained statehood and what changes in the security policy of these states have been brought about by the annexation of Crimea by Russia and the conflict in the eastern part of Ukraine?

The author presumes that the dynamically changing security environment in Eastern Europe, which is a result of the political and military activity of Russia, may strongly determine the political and military situation in the region. One of the results of this influence is changes in the defence doctrines and strategies of the Baltic States. In the course of further considerations, the above-mentioned hypothesis will be subject to verification with the assumption that the changes occurring in the security environment in Eastern Europe are of a permanent character and will not change their nature in the foreseeable future.

The time horizon of the research covers the period from the end of the World War I up to the present moment. The recent decades represent a fundamental period in which statehood was shaped and the directions of policies leading 
towards integration with the desired structures that were to provide the Baltic States with a sense of security were developed. In the research, the course and results of which are given below, we have adopted an analysis of the literature and source documents of doctrinal character relating to the Baltic States as the main research method. The overall work is to present the reaction of the Baltic States to the changes which have occurred in the neighbouring areas in the security environment.

\section{Historical circumstances}

Estonians, Latvians and Lithuanians of today are the heirs of different traditions. These nations, which live in a relatively small area on the eastern shores of the Baltic Sea, constitute a separate political and cultural entity on the international stage and often act together, presenting their points of view. The history of the nations living in today's Baltic States is marked by conflicts with stronger neighbours: Russia, Poland, Sweden, Denmark and German settlers. It should be noted that despite many similarities in modern times - size, location, natural resources or potential - the development of these countries has been carried out in different ways over the centuries.

However, from the point of view of the undermentioned considerations, in order to discover the causes of these directions of security policy of the Baltic States, it is enough to refer to the end of the World War I, which is when these states regained their independence.

By creating their own, separate national cultures, Estonians and Latvians sought to reduce German influence and Lithuanians to reduce Polish influence. To this end, they have consciously shifted their focus to the cultures of Western Europe, especially French and English. Many people in Latvia and Estonia changed their German-sounding names to more familiar ones and the use of peripheral languages or dialects was perceived badly in all three countries (Kasekamp 2013, p. 119). The policy towards national minorities in Lithuania, especially towards Poles, differed in its rhetoric from the policy towards national minorities in Latvia and Estonia. There has been no radical change in the treatment of national minorities in these two countries. However, it should be noted that the Latvian 
and Estonian authorities treated the Baltic Germans, who had been deprived of the privileges they had enjoyed for several hundred years, the least favourably (Kasekamp 2013, p. 122).

Given the common interest in security, cooperation between the Baltic States has not progressed as well as expected. There were differences in risk perceptions between the Baltic States. For Estonia, Soviet Russia was a potential enemy; for Latvia, it was both Russia and Germany; while the Lithuanians in Soviet Russia saw counterbalances against Poland, with which the Latvians and the Estonians had increasingly close contacts. In addition, Lithuania had quite difficult relations with Germany. The relations between Lithuania and Germany became even more complicated after Hitler came to power. At that point, the region of Klaipeda, formerly in German possession and taken over by the Lithuanians after World War I, became a problem once again (Kasekamp 2013, p. 126). Whereas, the dispute over Vilnius, mentioned earlier, stood in the way of an agreement between Poland and Lithuania.

In February 1921, Latvia and Estonia, through the recognition of Lithuania, brought the Balts closer together. The Latvian Foreign Minister, Zigfrids Meierovics, even proposed the creation of a Baltic Union of Latvia, Lithuania and Estonia, although there was an unofficial talk of a union with Poland and Finland as well. Lithuania was inclined to support the Latvian concept of the "tristate" Baltic Union, and the other Baltic States, as a consequence of accusations in the Estonian press of Polish adventurism and imperialism, seemed more inclined to establish a link with Estonia, Finland, Latvia and Lithuania with the exclusion of Poland (ŁukasikDuszyńska 2008, p. 194).

As a result of negotiations, representatives of Poland, Latvia, Estonia and Finland signed an agreement on 17 March 1922 in Warsaw consisting of nine articles. In the event of an indiscriminate attack on a signatory, Article 7 obliged the other allies to maintain a friendly attitude towards the attacked state and to agree on necessary measures to be taken. Since its ratification by the last signatory, the agreement was to enter into force for a period of five years, with the possibility of tacitly agreeing on a yearly extension. However, this agreement did not enter into force because it had not been ratified by Finland. The main reason why the Finns rejected the agreement was the fear that in the event of the Germans attacking Poland, they would be obliged to fight the country with which they wanted 
to maintain good relations. For the Finns, the idea of allying with Poles became increasingly troublesome (Łukasik-Duszyńska 2008, p. 199-203). Another conference of the three Baltic States and Poland, without Finland, took place in Warsaw. The topics discussed were: economic cooperation, cultural approximation, exchange of information and the current political situation in the region. Matters concerning joint defence commitments were not included in the final protocol of the conference (Lossowski 1995, p. 254).

However, efforts to strengthen cooperation between the three Baltic States continued. In 1934, these countries signed a treaty on understanding and cooperation, which, however, was limited only to diplomatic and cultural cooperation. Issues relating to the security of the Baltic States were linked to the League of Nations. When in the mid-1930s, the position of the organisation began to weaken, partly as a result of an agreement between Germany and the United Kingdom, which practically put the Baltic Sea under the control of Germany, the Baltic nations tried to seek help in declarations of neutrality. Unfortunately, as it turned out later, it did not stop the aspirations of either the USSR or Germany. The independence of the Baltic States, which had been won over with such difficulty, was lost after only twenty years. It should be mentioned that the international community was quite sceptical about the Baltic States. In Western European countries at the beginning of the 1920s in particular, there was a widespread opinion that the Baltic States could not survive on their own. They failed to survive, but the reason was not the inefficiency of state structures; they were (just like Poland) the victims of the German-Soviet collusion on the division of spheres of influence.

Although Lithuania, Latvia and Estonia proclaimed neutrality during World War II, this did not protect them from participating in the war. The annexation of the Baltic States by the USSR took place in the summer of 1940. In the spring of 1941, national armies of the Baltic States were transformed into territorial corps of the Red Army, and most of the officers who did not want to submit to the Red Army were shot (Motyka, Wnuk, Stryjek, Baran 2012, pp. 17, 35, 57). The secret police of the NKVD started surveillance, resulting in arrests and deportations of "enemies of the people" with their entire families to Siberia (Kasekamp 2013, p. 135).

Due to the barbaric Soviet policy towards the population, the entry of German troops into the territory of today's Baltic States was accepted by Estonians, Latvians 
and Lithuanians with a certain relief. In Estonia and Latvia, the period from the incorporation into the USSR in June 1940 to the entry of the Wehrmacht in July 1941 is called the "year of horror" (Motyka, Wnuk, Stryjek, Baran 2012, p. 36).

During the fighting between the Third Reich and the Red Army, the citizens of these countries very often switched to the German side in order to return home. Lithuanians, Latvians and Estonians (like Poles during the First World War) often had to fight on opposite sides of the barricade. In turn, the Hague Convention did not allow for mobilisation in the Waffen-SSS (the military arm of assault troops, formally independent of the German army) in the occupied territories of Eastern Europe. Germans, violating the international law of conscripts, listed these soldiers as "volunteers". At this point, it is worth emphasising that it was only Poles and Lithuanians who did not form such units in the Europe ruled by the Germans (Kasekamp 2013, pp. 141-142).

At the beginning of 1944, the situation changed, when the Red Army was approaching the borders of the Baltic States. In occupied Latvia, about 160,000 volunteers had been conscripted by July 1944. Even in the last days of the war, one of the Latvian legions fought fanatically among Berlin's burning buildings (Palmer 2008, p. 397). The situation was different in occupied Lithuania. The promise that their Lithuanian unit would operate only in the territory of Lithuania and only under the command of Lithuanian officers resulted in the recruitment of 20,000 volunteers. The Germans, however, changed their minds because they began to suspect that the seeds of a Lithuanian national army were being formed in front of their eyes. They tried to deploy the Lithuanians in various units commanded by German officers. When they demanded an oath of allegiance to Hitler, Lithuanians started to go AWOL on a large scale. Most of them fled with weapons in their hands, later creating points of armed resistance against the Soviet authorities (Kasekamp 2013, p. 143).

Despite the efforts made and the hopes that came with the political and military changes that took place between 1939 and 1945, the Baltic nations did not manage to win their own statehood and the Russians, after the Tehran conference, were given a free hand to reimpose their will on the Baltic States. It took more than 50 years for the Baltic States to rebuild their own statehood, up until the collapse of the USSR. 


\section{Reclaiming independence - shaping security policy}

During the 50 years of Soviet presence, the authorities in the Baltic States had created very solid structures that had controlled almost all spheres of social activity, making it impossible for societies to make any changes. The legacy of the structures of the former USSR, and especially its former staff, who mostly remained in the area, even now allows the Russian Federation services to effectively influence the political situation of these countries. The possibility of political transformation in the USSR itself and the revival of independence movements in the republics that were part of the union and wanted to have independent states came with the 1985 appointment of Mikhail Gorbachev, the General Secretary of the Central Committee of the CPSU. Gorbachev wanted the USSR to become a state able to compete with the West. To achieve this, he introduced the "glasnost" and "perestroika" policies in 1986. The Baltic States decided to seize the opportunity.

In the summer of 1988, patriotic activity intensified. In Estonia, Latvia and Lithuania, banned national flags began to flutter in the wind. In August 1988, Estonian dissidents founded People's Front, the first non-communist political party. In October 1988, mass patriotic rallies took place and the fronts of the three Baltic States held their founding congresses and committed themselves to cooperation, becoming a model for informal democratisation processes throughout the USSR (Kasekamp 2013, pp. 168-170).

In May 1989, on the initiative of MPs of the People's Front, the first Baltic leaders' meeting took place in Tallinn, and a month later the first meeting of the established Baltic Council consisting of presidents and top state officials was held to discuss common problems during regular meetings (Kasekamp 2013, p. 168). The Baltic Assembly was established in November 1991 as a body of 60 parliamentarians to meet twice a year to coordinate foreign policy and to establish relations with Russia and other post-Soviet republics (Palmer 2008, p. 436). The later objective of the Baltic Assembly was integration with the structures of the European Union and NATO.

In autumn 1989, the then leader of the Communist Party of the Soviet Union, Mikhail Gorbachev, wanted to save the empire and proposed a new trade union treaty to the Baltic states transforming the Soviet Union into a loose federation of 
republics, in which the states would have wide economic autonomy. However, the quest for independence was very strong in the Baltic States and took institutional forms. The first free elections to the Supreme Soviet in the spring of 1990 resulted in people's fronts gaining majority support in all three Baltic republics (Palmer 2008, p. 436).

Thus, after 46 years of Soviet rule, the process of gradual independence of the Baltic States began. The new authorities in the capitals of these countries embarked on the difficult process of building state structures and shaping their countries' security policies on the basis of the changing geopolitical realities surrounding them. International recognition was the only thing lacking for full sovereignty to be achieved. Of course, the case of the Balts was an issue that still enjoyed some support, but the international community's priority at the time was to back the reforms initiated in the USSR by Gorbachev and to end the Cold War.

The Nordic and Eastern European countries as well as the Russian Soviet Federative Socialist Republic (ruled by Yeltsin) were the first to recognise the independence of the Baltic States, followed by other countries in the last week of August and the USSR on 6 September 1991. Lithuania and the other Baltic states were admitted to the United Nations on 17 September 1991. Although the Baltic States' independence is generally linked to the collapse of the USSR, the opposite seems to be closer to the truth. It was these popular movements in the Baltic States that increased the pace of democratisation within the USSR and undermined the foundations of the empire.

\section{Lithuania}

The beginning of the 1990s brought a consensus among all major political forces in Lithuania as to the choice of future direction of security policy. Lithuanians identified three main sources that could negatively affect their country's security in the future:

- external threats resulting from the unfavourable geopolitical situation of the country;

- political influence from Russia;

- an increase in organised crime. 
At the same time, the Lithuanian political class voted almost unanimously in favour of integration with Western political and military structures. This choice was reflected in the Constitutional Act of 8 June 1992 "on the Republic of Lithuania Refraining from Entering into Agreements with the Existing Structures in the Post-Soviet Area". (Constitutional Act ... 1992).

At that time, about 50,000 Soviet soldiers were stationed in Lithuania. This was a major obstacle for an actual self-establishment process and the ability to create an independent security policy in real terms. The negotiations lasted for two years. The Lithuanian authorities believed that the presence of Soviet troops on their territory was a violation of international law, which took place in 1940, i.e. after the Soviet Union attacked Lithuania and then occupied its territory. As a result of negotiations at the turn of the years 1992-1993 and following the attempts to put pressure on Lithuania to withdraw from its independence efforts, an agreement was finally signed, as a result of which the last soldier left the territory of Lithuania in September 1993 (Kozakiewicz 2003, p. 14).

Lithuania made its first attempt at drawing up the initial assumptions of the security policy after the proclamation of independence on 11 March 1990 by the Socialist Republic of Lithuania. The creation of new structures for the future sovereign state began. One of the first was the Ministry of Defence, established in April 1990. The next step was to create documents that would serve as doctrinal foundations for the future activities of the state apparatus. Such a document was the "Outline of the concept of national security of Lithuania". It was a semi-legal document intended for a small group of Lithuania's political elite, which was already made available in October 1990 (Kozakiewicz 2003, p. 16). The authors of the document considered the policy of neutrality as the basis for the implementation of Lithuania's security policy, which, in the context of the geopolitical situation and the historical past, was then a short-sighted approach and now it can be said that it was even naïve. The elites quickly realised that Moscow did not want to give up its influence in the region. At that time, Russian Special Forces units of the OMON carried out numerous attacks and provocations. A particularly cruel event was the cold-blooded execution of seven Lithuanian border guards on 31 July 1991. This strategy was partly aimed at intimidation, but was mainly perpetrated to provoke Lithuanians to take violent steps. If they had committed violence, the Soviet authorities could have introduced direct presidential rule in 
the name of maintaining order. However, despite the pressure, the Lithuanians managed to stay calm (Kasekamp 2013, pp. 176-177).

As a result of the brutal steps taken by Moscow, another project of the concept of national security, developed by a group of scientists from the University of Vilnius at the turn of 1992-1993, drew attention to external threats and pointed to the need for closer cooperation with the West. In addition to the economy and the political sphere, the project strongly emphasised the problem of national identity and identified external threats resulting from (Kozakiewicz 2003, pp. 16-17):

- political tensions in bilateral relations;

- tensions surrounding the stationing of Soviet troops on Lithuanian territory;

- economic and political attempts to subjugate Lithuania;

- tensions with other countries of the Commonwealth of Independent States (imposing a common defence space);

- environmental threats from outside;

- the influx of social pathologies;

- a process called "brain drain".

The idea of close cooperation between the Baltic States and the Nordic countries has also emerged in this concept, which, for historical and geographical reasons, is their natural direction of activity. Moreover, a democratic and rich Scandinavia had great potential to support and build the democratic structures of the newly emerging Baltic States. In the 1990s, the Nordic countries engaged in this process primarily with a view to extending the zone of stability and development. This assistance included the transfer of used military equipment, training of soldiers and advice on preparing the armed forces of the Baltic States for NATO membership (Liik Kaljurand 2012).

The implementation of the concept of integration of military and security policy with the West began in 1993 with the signing of two bilateral agreements on military cooperation: with Poland and the Czech Republic, and with the United States of America, the Mil to Mil programme. Under this programme, Lithuania received military assistance through counselling and training of personnel. In 1994, Lithuania also obtained assistance in the form of devices, ammunition and military equipment from Germany, France and Denmark. Lithuania intensified its efforts in this period to move closer to NATO and the EU, and, as a result of these efforts, it joined the Partnership for Peace programme, became an associate 
member of the Western European Union and signed agreements between the Baltic States, the United Kingdom, Denmark, Norway, Sweden and Finland on the establishment of the Baltic Battalion of the Peacekeeping Force (BALT-BAT).

In 1996, the Lithuanian Parliament adopted a new concept of national security under the name of "the Act on the Assumptions of National Security of Lithuania". Its main message was to "develop and strengthen democracy, to ensure the safe existence of the nation and the state, to stop all potential aggressors and to defend the sovereignty, territorial integrity and constitutional order of the state". The reference points are: "human and citizen rights, fundamental freedoms and personal security; values of the nation, its rights and conditions for free development; independence of the state; constitutional order; integrity of the territory of the state; environment and cultural heritage". (Miniotaite 1999, pp. 16-17).

The most important external threats mentioned in the above-mentioned concept of national security include:

- the political ones: political pressure and dictate; instability preventing Lithuania from obtaining guarantees of international security; threats from foreign countries to use force on the pretext of defending their interests; attempts to impose discriminatory international agreements on Lithuania;

- the military ones: armed aggression; military transit through Lithuania; penetration of armed gangs into Lithuanian territory;

- the other ones: illegal immigration; transit migration; influx of refugees; attempts to force the rules of dual citizenship in Lithuania;

- the economic ones: economic pressure; blockade or other hostile economic activities; capital investment with political objectives.

Although the document does not refer to specific countries as a threat to Lithuania's security, anyone familiar with the reality of the region will easily notice that the threats classified as political, military, and partly economic are considered to originate from Russia (Miniotaite 1999, pp. 16-17). The strategy has been amended several times, but its basic ideas and guiding spirit have remained the same and are now the cornerstone of Lithuania's security policy.

Another novelisation from 2012 was criticised by opinion leaders in Lithuania. An example of such criticism is the provision in the document stating that "Lithuania, in order to prepare adequately for the country's independent and common armed 
defence ... will strengthen the military's combat capacity ... and increase its reserves". (National Security ... 2012). According to the critics of the document, this was unnecessary and very expensive, and the legitimacy of creating a reserve army was doubtful (Wołowoj 2012). It should be remembered that it was the year 2012 and the external conditions related to the existing potential threats were different as well. However, the annexation of Crimea in 2014 introduced a completely new reality. A fundamental change concerned the perception of Russia, providing evidence to those who, up to that point, had doubts about its intentions to rebuild its former sphere of influence.

The current National Security Strategy of Lithuania, approved by the National Defence Council on 14 March 2016 and adopted by the Lithuanian Parliament on 17 January 2017, sets out the threats, risks and risk factors to which national security institutions should pay special attention. These include (Seimas approved ... 2017):

- conventional military threats due to the readiness and determination of the Russian Federation to use its forces to achieve its objectives;

- implementation and development of Russian military capabilities in Lithuania's neighbourhood;

- military activity without transparency and demonstration of Russian military forces at the borders of Lithuania and other NATO member states;

- global and regional instability;

- terrorism, extremism and radicalisation;

- informational threats;

- cyber threats;

- economic and energy risks;

- economic dependence;

- development of unsafe nuclear technology along Lithuania's borders.

In this document, we already have a clear reference to the Russian Federation, identified as a factor that poses a real threat to the security and political stability of the state and the region. The strategy developed in 2016 is the fourth document of this kind since the restoration of the independence of the state. The priorities of the national security policy of the Republic of Lithuania and long-term tasks within the framework of the strategy include: 
- strengthening the country's defence capacity;

- strengthening of NATO's collective defence;

- strengthening crisis management and partnership within NATO;

- progress in solidarity and unity within the EU.

The strategy envisages a consistent increase in defence spending to at least $2 \%$ of GDP and a further steady increase in defence funds, as well as an increase in the combat power of the armed forces, with particular emphasis on: land-based combat capabilities, airspace surveillance capabilities, and the development of resource stockpile capacity. The new document was supplemented by additional requirements for the Lithuanian Armed Forces: a rapid transition from peace to military structure in order to maintain a high level of alertness and a rapid response to external and internal threats (Seimas approved ... 2017).

\section{Latvia}

The ethnic factor should be taken as the main point of reference determining the subsequent actions of the Latvian authorities when considering the issue of Latvia's security. As a result of Moscow's policy of intensive russification of Latvia for decades, at the verge of regaining their independence in 1989, native Latvians constituted only $52 \%$ of the country's population whereas Russians accounted almost for $33 \%$ of the country's population at that time. Other ethnic minorities living in Latvia include Belarussians (4.5\%), Ukrainians (3.5\%), Poles (2.3\%) and Lithuanians (1.3\%). The remaining national groups did not exceed $1 \%$ of the total population of the country (Eberhardt 1996, pp 55-56). Demographic forecasts at that time indicated that Latvians could become a minority in their own country. It is therefore not surprising that in the first years of independence, the Latvian authorities considered this threat to be the greatest. As a result, Latvia's national security policy was based on nationalist foundations.

An additional factor strengthening nationalistic trends in Latvia were the Soviet troops stationed in the number of about 40,000. Their withdrawal from the country, as in other post-Soviet countries, was a priority for Latvia. The negotiation process with Russia, which had begun in 1992, ended two years later with a series of unfavourable provisions for Latvia, such as the consent to leave 
demobilised soldiers and military pensioners in Latvia, the recognition of the right of Russian military structures to its own fixed assets on Latvian territory, and even the consent to operate a radar station located on Latvian land.

The first years of independence also saw the creation of security and defence structures. In September 1991, organisation of the National Guard and the Ministry of Defence, and later the Latvian Armed Forces and Border Guard Forces began. The State Defence Council was established to coordinate the entire state security policy. In 1994, a number of legal acts regulating the structure and system of state security were adopted (Kasekamp 2013, pp. 161-163).

In 1994, NATO decided to open its alliance to the countries of Eastern Europe, including the Baltic States. In the same year, there was also a change in the security policy instruments promoting the integration of society. The nationalist narrative was, therefore, abandoned under pressure exerted by international opinion. Since 1995, Latvia has started to emphasise that regional cooperation is not an alternative to becoming a member of the EU and NATO. The forms of cooperation of the Baltic States and those in which the Nordic countries participated lost their strategic dimension and Latvia treated them as integration training. However, its omission from the first round of pre-accession negotiations with the EU resulted in a decline in the popularity of the idea of integration with European structures in Latvian society (Kozakiewicz 2003, p. 33).

In 1995, the Latvian Parliament adopted the first "Concept of National Security". After several modifications, it was adopted as an official document under the name of the "Concept of Security of the Republic of Latvia". The provisions of the document lead to the conclusion that Latvia's ultimate goal is integration with NATO and the European Union. The ideas of neutrality and regionalism have therefore been abandoned in favour of international guarantees. Although the threat of one of the Baltic States was still treated as a common threat, the main objective was to integrate with the European Union and NATO (Bajarnas, Haab, Viskne 1995, pp. 50-52).

Subsequent modifications to the Latvian security strategies of 2005 and 2008 have not led to any significant changes in the substance of the security policy. The National Security Concept, approved in May 2012, identified the following as the main threats: proliferation of nuclear weapons; terrorism; radical extremism and 
piracy at sea; and cyber terrorism. It pointed out that Latvia should gradually increase its defence budget to $2 \%$ of GDP (The National Security Concept ... 2011). Like the Lithuanians in their 2012 document, the Latvians do not point to Russia as a direct threat to state security.

The current National Security Concept for 2016-2020 was approved in November 2015 and adopted on 16 June 2016 by the Latvian Parliament. The document focuses on the increasing threat from Russia, strengthening NATO's collective defence and presence in Latvia, intensifying military cooperation with key allies and developing its own defence capabilities. The strategy identifies eight main threats to Latvia's security. These are related to (The National Security Concept ... 2011):

- external threats;

- intelligence and special services of foreign countries;

- military threats;

- social threats;

- informational threats;

- economic challenges;

- international terrorism;

- cyber terrorism.

The priorities set out in the adopted document include the need to strengthen the borders, improving refugee policy and preventing the risk of their radicalisation. According to the authors of this strategy, in order to avoid threats posed by the foreign intelligence service and special services, Latvia should develop its national security and counter-intelligence service and pursue a prevention policy. The country should also develop public media, reduce the influence of the Russian media, control foreign investment and ensure a stable energy supply (Latvian parliament approves ... 2011).

According to that document, Latvia is aware of the Russian threat. However, its situation is not easy. Preparations for possible aggression or provocation by Moscow are not facilitated by the Social Democratic Party "Harmony", which disregards the threat from Russia and fights for better treatment of the Russian minority. 
As shown by data from 2017, Latvians constitute $62 \%$ of the total population of their own country and Russians 25.4\% (The World Factbook, 2017). Comparing the data from 1989, we can see that the Russian population in Latvia recorded quite a spectacular decline - 30 years earlier, Russians made up almost 33\%. At the same time, there was an increase in the percentage of the Estonian population, which from the point of view of the state is obviously very important. However, the Russian minority, constituting a quarter of society, still does not allow the authorities in Riga to sleep peacefully. Latvia is therefore anxiously looking at its eastern land border. The reason for this is a large Russian national minority, which may be a reason for the Kremlin to undertake actions which could destabilise the Latvian state. The maritime border and airspace of the Baltic States are also regularly provoked. For several years now, we have been dealing with violations of the territorial waters and airspace there.

\section{Estonia}

Similarly as in the case of the other Baltic States, the first ideas related to the development of national security policy in Estonia have already emerged in recent years, when perestroika elites, observing the international situation, expected, to a certain extent, the collapse of the socialist system. Discussions on the shape of the new political order were mainly conducted by the dissident circles and mostly concerned the neutrality of the reborn Estonian state. Neutrality seemed to be the best, if not the only, option for Estonia's sovereign existence at the time. (Bajarnas Haab Viskne 1995, pp. 29-30). The supporters of this solution stressed the lower costs of such a solution, in particular the argument of avoiding conflicts with Russia. Given that the neutrality option was supported by the Russian minority and by Russia itself, it did not gain support among Estonians. In the end, the conviction that resignation from NATO could leave Estonia in a grey area of security prevailed.

Since the proclamation of independence in 1991, work has started immediately on the future concept of security for sovereign Estonia. During the first years of independence, particular emphasis was placed on the problem of the defence of Estonia and its armed forces. This was due to the elite's conviction that the 
source of national security was the independence and strength of the state. One of the first decisions of the Estonian Supreme Council was the decision of 3 September 1991 to establish the National Defence Force. A dispute over the size and tasks of the armed forces built from scratch arose among the elites. Estonia is the country with the least potential and is also the least favourably placed among the 3 Baltic states. The source of the lively discussion was a typical dilemma for a small state which could not ensure its own security with its own armed forces. A central element of Estonia's security policy at the time was the concept of total defence, which consisted in simultaneous action by all state structures, especially the armed forces supported by the entire nation.

Also in the case of Estonia, internal factors played an important role in shaping the future security and defence policy. The most important of these was the fact that Soviet troops were stationed on the territory of Estonia. Estonia, like the other Baltic States, wanted to bring about a swift agreement with Russia on this issue. The negotiation process was protracting, which allowed the Russians to obtain more favourable provisions than in the case of the other Baltic States. The agreement on the withdrawal of Soviet troops from Estonia was not signed until June 2004. According to the agreement, Russian troops were to leave Estonia in July 2004. In practice, 1000 Russian soldiers remained on Estonian territory. Due to the fact that Estonia was the most militarised area of the USSR (there were from 100,000 to 135,000 soldiers stationed there), it was difficult for the authorities to determine their relocation. 2\% of Estonia's territory was administered by military authorities. The only training centre for nuclear submarine crews in the USSR was established near Tallinn. To this day, the majority of Estonians show a permanent syndrome of prejudice against Russians (Kozakiewicz 2003, p. 42). Russia, on the other hand, is invariably perceived in Estonia as the main and even only threat. Threats from Russia have been the basis of Estonian national security policy to date.

This feeling is further reinforced by the unfavourable ethnic composition of Estonia as well as by the emigration processes, which took on a dangerous dimension at the beginning of the 1990s. Almost 90,000 people emigrated from Estonia, with its population count at 1,300,000. For such a small country, this is a significant amount. Just as in Latvia, Russians constitute a significant ethnic group in Estonia. 
Such a situation was caused by the ethnic policy of the USSR and biological losses among the ethnic Estonian population, combined with systematic Russification. However, the situation did not look so unfavourable in the country as a whole. According to the general census of 2000, the population of Estonia was 1370 thousand (PC222: POPULATION ..., 2000). Estonia's society consisted of: Estonians who constituted $67.9 \%$ of the entire society, Russians (25.6\%) and Ukrainians (2.1\%), Belarusians (1.2\%), Finns (0.9\%) and other nationalities (2.2\% Tatars, Latvians, Poles, Jews, Lithuanians, and Germans). According to the second general census conducted in 2011, 1294.4 thousand people lived there. Estonians constituted 69.7\%, and Russians 25.2\%. Looking at the result of the general census of 2001, we can see that the number of Russians decreased, and the number of Estonians increased. It does not change the fact that in the Ida-Viru County (149.2 thousand inhabitants), which is the third in terms of the size of population, Estonians constitute only 19.5\%, and Russians 72.5\% (PC0428: POPULATION ..., 2011) and they overtly show secessionist attitudes. As a result, Estonia, like Latvia, started to apply very restrictive procedures for granting citizenship.

Taking all these factors into account, Estonians have taken the threats from Russia as the basis for their national security policy. These include (Kozakiewicz 2003, pp. 43-46):

- resurgence of Russian imperialism;

- the possibility of rebuilding the Russian totalitarian state;

- initiating internal conflicts in Estonia in order to influence the course of events;

- the possibility of economic and political structures in Russia collapsing;

- subversive activities in Estonia;

- manipulating the Russian-speaking minority.

The consequence of the threats formulated in such a way was a strategy of a "hard course" towards Russia. The political support given by Estonia to the West during the negotiations on the withdrawal of Russian troops convinced Estonians that in the event of a conflict, the west would take the side of Estonia. Over time, however, under the influence of changing geopolitical realities, the strategy of a "hard course" towards Russia weakened. In the years 1997-98 Estonian-Russian relations improved. Estonia started accession negotiations with the EU and NATO. At the same time, Russia was proposing unilateral security guarantees to the Baltic 
States in exchange for withdrawing from applying for NATO membership. The Baltic States rejected Russia's proposal and upheld declaration of its willingness to join NATO and the EU. The Estonian authorities worked in this direction with equal intensity. As a result of the consistent actions of the government and elites in 1997, Estonia was designated by the European Commission as the leader of pre-accession procedures; however, it did not help it accede more quickly to the EU structures.

In the concept of national security adopted by the Estonian Parliament in 2001, the notion of nation as the basic source and subject of security policy was replaced by the concept of "Estonian society".(Möller 2007, p. 158). This ostentatious change in the way we think about security has given observers the impression that it is a political exercise designed to produce the effect of portraying Estonia as a country free from nationalism.

The risks identified in the new security concept are mainly characterised as economic ones (Möller 2007, pp. 158):

- global recession or shocks in markets important for Estonia;

- dependence on imports of energy resources from a single source (gas, oil);

- Russian transit;

- dependence on the Russian energy market.

Among the security threats identified in the concept, it is difficult to find direct military threats, either now or in the future. There are also no threats of possible political pressure from outside, which could threaten Estonia. In contrast to the threats contained in the previous document, these are threats that do not relate directly to Russia. This document gives the impression that Estonia has no problems other than those mentioned above and that the existing threats will disappear once it joins NATO and the EU.

In May 2010, the parliament passed another "National Security Concept" and on its basis, the government approved the National Security Strategy of Estonia. It is a document currently in force and has not yet been amended.

The document states that although there are no existential threats to the security of NATO member states, the global and regional security environment is becoming more dynamic and unpredictable. New threats and challenges have emerged, while traditional security issues have not disappeared. The potential risks for Estonia 
come from hybrid challenges and mixed risks, as well as from a combination of internal and external factors. The authors of the document are of the opinion that national defence can no longer be limited to military defence, they claim that only a comprehensive approach to defence can guarantee the security of the country. Based on this main idea, the 2011 National Defence Strategy foresees that all major Estonian state authorities will participate in national defence, thus combining the capabilities of the armed forces with those having non-military defence capabilities. Looking further at the document, it can be seen that the main principle of Estonian defence policy is to ensure security for itself by its own means, with the support of its allies. The document also points to the need for active involvement in crisis management and peace support operations conducted by various international organisations (National Defence Strategy ... 2011).

Another document defining the direction of changes and the amount of expenditure on defence, as well as the requirements for the capabilities of the armed forces, all based on the National Military Strategy, is the National Defence Development Plan 2013-2022. It states that by 2022, Estonia will have formed a second infantry brigade fully assembled and armed, which will significantly increase the defensive potential of the state. Estonia also wants to strengthen its ability to fight an enemy's armoured forces. In addition to the above, the development plan also foresees the need to have tanks with high manoeuvrability and medium range air defence capabilities. Due to financial constraints, Estonia only plans to achieve these capabilities in 2022 (National Defence Development ... 2013). It is clear that Estonia, like Lithuania and Latvia, is aware of the growing threat from its powerful neighbour.

\section{Conclusion}

During the first few years after regaining independence, the Baltic States considered several security policy options: neutrality or lack of alliances; tripartite alliance (with close military cooperation with the Nordic countries); and a third option, NATO and EU membership. Due to the Russian soldiers stationed on the territory of the Baltic States and the influence Russia had on their internal situation, at that time, they could not afford to direct their diplomatic efforts unequivocally 
towards integration with western structures. Nevertheless, the policy of the Baltic states was based on shaping a positive image of the west and on an increasingly bold critical presentation of Russia's image as a country which posed a threat to its security, and the efforts of successive governments were directed towards integration with sub-regional, pan-European and transatlantic international cooperation structures.

With the withdrawal of the Russian garrison, the Baltic states increasingly boldly articulated their aspirations to become members of NATO and the EU. In the second half of the 1990s, this became the main objective of their foreign and security policy. Before it happened, however, the Baltic States had become members of the United Nations and the OSCE/CSCE in 1991 and had become associate partners of the Western European Union in 1994 (Górka - Winter 2002, p. 479) and had signed association agreements with the European Union.

The concept of joint allied defence within the North Atlantic Treaty Organisation has been identified as preferable to the concepts of neutrality mentioned above (e.g. following the example of Finland) or tripartite alliance with strong links to the Nordic countries. The concepts of creating a regional, separate security system (e.g. "Eastern NATO") or signing a collective security agreement between the Commonwealth of Independent States also seemed unattractive in the perspective of civilisational, technological and economic development. The Baltic States also rejected the idea of accepting a security guarantee from the Russian Federation. In non-military matters, the Baltic States decided to actively pursue their interests within the Council of the Baltic Sea States (Górka-Winter 2002, p. 479).

While the participation of the Baltic States in the UN, OSCE and EU did not raise any concerns among their neighbours, the prospect of them joining NATO was a matter of discussion. Although Russia has repeatedly reaffirmed the right of each state to choose freely how to ensure its own security, it has not seen a need for such a solution, and every step of NATO closer to the borders of the Russian Federation has been interpreted by the Kremlin as a threat to Russia. Also, Belarus, as claimed by President Lukashenko, did not hide in its statements of that period the suspicion that the countries of the Treaty and the candidate countries have downright hostile intentions towards Belarus. 
The aspirations of the Baltic States were also met with distance from Sweden and Finland, which are still outside NATO. These countries were afraid not so much of Russia's reaction as of the need to redefine their own security policies - questions about the sense of neutrality still remain valid both in Sweden and Finland. Sweden and Finland encouraged the Baltic States in particular to make efforts to join the structures of the European Union, which was at the time in the process of implementing the European Security and Defence Policy (ESDP), and to cooperate within the framework of the NORDEFCO (Nordic Defence Cooperation) Agreement.

Strengthening economic cooperation with the Scandinavian countries (the largest investors in the Baltic States) is also conducive to developing cooperation in the field of security. On one hand, the Scandinavian countries are interested in doing so, both because of the wider security of the Baltic Sea and because of the potential benefits for their defence industries. On the other hand, it should be mentioned that there is practically no arms industry in the Baltic States, which means that these countries are forced to import (almost entirely) arms for their armed forces (Pacuła 2013, p. 59).

Joining NATO in 2004 not only increased the sense of security in the Baltic States, but also extended the area of stability on the European continent to the newly joining member states. The Baltic States are actively involved in alliance projects and their contribution to foreign missions, taking into account their population potential, was one of the largest in NATO. These countries present a position identical to Poland in many key aspects of security policy, which often results in joint actions within the ranks of NATO (Pacuła 2013, pp. 58-59). Through joint lobbying to strengthen collective defence, Lithuania, Latvia and Estonia were included in the Eagle Guardian contingency plan in 2010.

There has been a completely new situation since 2014, when Russia annexed the Crimea and became involved in the conflict in eastern Ukraine. The new reality meant that one of the first steps taken by Lithuania was to restore the basic military service in March 2015 by the Lithuanian Parliament.

Although the Baltic States consider armed aggression to be unlikely, they do not rule it out. The authorities of these countries believe that Moscow, which has long pursued a very aggressive policy towards them, using various forms of pressure, 
is threatening their stability and even the territorial integration of the region. An attempt to restore influence or even subjugate the former Soviet republics is very real. For example, in order to have a land connection with the Kaliningrad Oblast, which, due to its strategic location, plays a huge role for Russia. Moreover, the location of the Baltic States creates a natural political and military line between Russia and broad and independent access to the Baltic Sea.

The Baltic States became aware of Russia's intention to rebuild its former sphere of influence as early as in 2008, after the war in Georgia. The annexation of Crimea by Russia only confirmed the Balts desire to strengthen their defence capabilities. Even before 2014, the Baltic States were among the first to signal Russia's desire to regain the status of a global power and the increase in tensions between Russia and NATO. In their 2010-2012 strategy documents, the Baltic States decided to devote more attention to conventional threats, foreign security operations and cyber security. In 2012, Lithuania and Latvia announced a gradual increase in defence spending to $2 \%$ of GDP. In response to Russian actions, the Baltic States have intensified their efforts to increase their own military capabilities and to ensure a permanent presence of NATO forces on their territory, which was the main objective of Lithuania, Latvia and Estonia at the NATO summit in Warsaw in July 2016. At the beginning of 2017, NATO deployed four battalion groups in the Baltic States and Poland.

\section{Bibliography}

Bajarnas E., Haab M., Viskne I., 1995. The Baltic States: security and defence after independence. Chaillot paper no 19, Institute for Security Studies, [online]. Available from: https://www.iss.europa.eu/sites/default/files/EUISSFiles/cp019e.pdf [Accessed 16 Aug 2018].

Constitutional Act on Non-Joining by the Republic of Lithuania of any Post-Soviet Eastern Alliances, Vilnius 1992, [online]. Available from: https://e-seimas.lrs.lt/portal/ legalAct/lt/TAD/TAIS.21154?jfwid=1clcwot6i3 [Accessed 16 Jun 2017].

Eberhardt P, 1996. Między Rosja a Niemcami. Przemiany narodowościowe w Europie Srodkowo-Wschodniej $w X X$ w. Wydawnictwo Naukowe PWN, Warsaw,

Górka-Winter B., 2002. Miejsce państw bałtyckich w europejskiej architekturze bezpieczeństwa - perspektywy. Biuletyn PISM 46. 
Seimas approved the National Security Strategy, Lietuvos Respublikos Seimas 2017, [online]. Available from: http://www.lrs.lt/sip/portal.show?p_r=119\&p_k=2\&p_ $\mathrm{t}=168691$ [Accessed 18 Jun 2017].

Kasekamp A., 2013. Historia państw bałtyckich. PISM, Warsaw.

Kiaupienė J., 2010. Wielkie Księstwo Litewskie i wielcy książęta litewscy w XVI wieku: refleksje nad litewskim narodem politycznym i unia lubelską. In R. Butterwick (ed), Rozkwit i upadek I Rzeczypospolitej, Bellona, Warsaw.

Kozakiewicz J., 2003. Polityka bezpieczeństwa państw bałtyckich. Fundacja Instytut Studiów Strategicznych, Krakow.

Lane T., 2007. Ofiary Stalina i Hitlera. Świat Książki, Warsaw.

Latvian parliament approves national security strategy, EurAsia Daily 2015, [online]. Available from: https://eadaily.com/en/news/2015/11/27/latvian-parliamentapproves-national-security-strategy [Accessed 21 Jun 2017].

Liik K., Kaljurand R., Baltic-Nordic-US cooperation as a vehicle for democratic change, International Center for Defence Studies 2012, [online]. Available from: http://www. icds.ee/fil leadmin/failid/Baltic-Nordic-US\%20cooperation\%20as\%20a\%20vehicle\%20 for\%20democratic\%20change.pdf [Accessed 10.05.2017].

Łossowski P., 1995. Stabilizacja pozycji międzynarodowej Polski (czerwiec 1921 - marzec 1923). In M. Leczyk, P. Łossowski, W. Materski, W. Michowicz, A. Skrzypek (eds), Historia dyplomacji polskiej, vol. 4 1918-1939, Wydawnictwo Naukowe PWN, Warsaw.

Łukasik-Duszyńska M., 2008. Brytyjskie poselstwo donosi. Posłowie brytyjscy wobec stosunków Polski z państwami battyckimi w latach 1920-1926, Szkoła Wyższa Psychologii Społecznej, Warsaw.

Malewicz P., 2008. Polska polityka wschodnia w latach 1989-1991. Europejskie Centrum Edukacyjne, Toruń.

Miknys R., 2011. Ogląd historyczny stosunków polsko-litewskich na przebiegu wieków. [online]. Available from: http://www.stosunki.pl/?q=content/ogl\%C4\%85dhistoryczny-stosunk\%C3\%B3w-polsko-litewskich-na-przebiegu-wiek\%C3\%B3w [Accessed 15 Jul 2017].

Miniotaite G., 1999. The security policy of Lithuania and the "integration dilemma". Lithuanian Institute of Philosophy and Sociology, Wilnius.

Möller F., 2007. Thinking peaceful change. Baltic Security Policies and security Community Building. Syracuse University Press, Syracuse-New York.

Motyka G., Wnuk R., Stryjek T., Baran A., 2012. Wojna po wojnie. Antysowieckie podziemie w Europie Środkowo-Wschodniej w latach 1944-1953. Scholar, Gdańsk-Warsaw.

National Defence Development Plan 2013-2022, Estonian Ministry of Defence 2013, [online]. Available from: http://www.kaitseministeerium.ee/sites/default/files/ elfinder/article_files/national_defence_development_plan.pdf. [Accessed 25 Jan 2018]. 
National Defence Strategy Estonia, Estonian Ministry of Defence 2011, [online]. Available from: http://www.kaitseministeerium.ee/sites/default/files/elfinder/article_files/ national_defence_strategy.pdf [Accessed 23 Feb 2018].

National Security Strategy of Lithuania 2012, [online]. Available from: https://www.files. ethz.ch/isn/156893/Lithuania\%20-\%20NATIONAL\%20SECURITY\%20STRATEGY. pdf [Accessed 08 Jan 2018].

Pacuła P., 2013. Współpraca obronna w regionie Morza Bałtyckiego. Stan obecny i perspektywy, Bezpieczeństwo Narodowe nr 26, BBN.

Palmer A., 2008. Pótnocne sqsiedztwo. Historia krajów i narodów Morza Bałtyckiego. Książka i Wiedza, Warsaw.

PC222: POPULATION, 31 March 2000 by Sex, Place of residence and Ethnic nationality, [online]. Available from: http://pub.stat.ee/px-web.2001/Dialog/Saveshow.asp [Accessed 24 Jan 2018].

PC0428: POPULATION, 31. DECEMBER 2011 by Ethnic nationality, Place of residence and Sex, [online]. Available from: http://pub.stat.ee/px-web.2001/Dialog/Saveshow. asp [Accessed 22 Sept 2017].

Seimas approved the National Security Strategy. Lithuanian Seimas homepage 17 January 2017, [online]. Available from: http://www.lrs.lt/sip/portal.show?p_r=119\&p_k=2\&p_ $\mathrm{t}=168691$ [Accessed 23 Jan 2018].

Subocz J., 2012. Litewskie spojrzenie na Wielkie Księstwo Litewskie i stosunki z Polakami. IEŚW Lublin, [online]. Available from: http://www.iesw.lublin.pl/projekty/pliki/ IESW-121-02-08.pdf [Accessed 23 Jul 2017].

The National Security Concept of the Republic of Latvia, Latvian Saeima 2011. [online]. Available from: http://www.mod.gov.lv/ /media/AM/Par_aizsardzibas_nozari/ Plani,\%20koncepcijas/2011_EN_ND.ashx [Accessed 27 Jul 2017].

The World Factbook, 2017. Latvia. Central Intelligence Agency, [online]. Available from: https://www.cia.gov/library/publications/the-world-factbook/geos/lg.html [Accessed 13 Feb 2018].

Wołowoj W., 2012. New Lithuanian National Strategy. Geopolityka 2012, [online]. Available from: http://www.geopolitika.lt/?artc=5513 [Accessed 16 Jul 2017]. 